\title{
Descriptive Analysis on the Plays of Wayang Kekayon Khalifah: A Collaboration Among Calligraphy, Wayang Arts, Islamic Dialogue, and Java Culture
}

\author{
L Lutfianto* \\ Islamic Education Concentration \\ UIN Sunan Kalijaga \\ Yogyakarta, Indonesia \\ lootfie80@gmail.com
}

\author{
Abdul Munip \\ Arabic Language Education \\ UIN Sunan Kalijaga \\ Yogyakarta, Indonesia \\ abddul.munip@uin-suka.ac.id
}

\begin{abstract}
Islamic art in the archipelago is not only in the form of calligraphy and mosque designs but also in the form of Wayang or puppetry. One example is Wayang Kekayon Khalifah Yogyakarta. Wayang uses calligraphy as a means of writing down the names of the actors and existing symbols and collaborating with the puppet culture. The author not only presents Wayang Kekayon Khalifah Yogyakarta as a spectacle but also as a guide or education on Islamic teachings. It aims to help readers understand the Wayang Kekayon Khalifah Yogyakarta. The results showed that the Wayang Kekayon Khalifah Yogyakarta contained calligraphy and wayang arts as well as dialogue between Islam and Javanese culture. So that the teachings of Islam as the basic capital of national character education can be conveyed with wisdom and beauty.
\end{abstract}

Keywords-calligraphy art, Wayang Kekayon Khalifah, Islamic teaching guidance, national character education

\section{INTRODUCTION}

Puppetry is still a unique performing art. The uniqueness of the puppet lies in the combination of various arts in the puppet show. Some of the arts that are integrated into it are literature, theater, music, tone, and so on. This uniqueness rises its own aesthetic. As Sumarsam said about puppetry in general, that aesthetics in puppetry is related to its auditory presentation. The white cloth presentation as well as the narrative and dialogue uttered by the mastermind that can enlighten the audience. Thus, the settings can be easily recognized. Moreover, the use of literary language style that is full of sound gives a deep psychological effect to the listener [1].

The puppets that exist today, developed from the puppets of the previous period. Puppets evolved from the shadows of their ancestors during the time of animism-dynamism. The shape of the puppet is not as it is now which is made of leather and full of alluring decorations. They used to be made of stone dolls as personifications of the shadows of ancestral spirits. Further development uses the reliefs of Prambanan temple, Penataran temple, and Jago temple.

Until the next period, in pursuit of their practicality, it was drawn on paper/cloth, which can be seen in Wayang Beber. Then with technical and aesthetic considerations, the puppets might look more "alive" and can be moved easily. Then the shape of the hand that was originally sliced (not separated) was cut into such that it can be moved.

Wayang (in this case Wayang Kulit Purwa) has an important role in the life of the Javanese people. Puppets become a symbol of life. Puppetry is also an art that contains various aspects of culture. One of them is used to educate/teach ethics and morals in non-formal education [2].

Wayang with various forms is used as a means of education in society, one example is Wayang Suluh which was made into a movie. This movie was made by the Information Office of the Republic of Indonesia in 1947. Wayang Suluh takes the story of the struggle for independence. It was used as a fuel and illumination (susuluh) to trigger the spirit of struggle against the Dutch. Visualization of the figures includes Bung Karno, Bung Hatta, and Bung Tomo.

In addition to the puppetry above, there are still puppetries that take the story of the history of the Kingdom of Yogyakarta. There is also Wayang Dupara which takes the story of the social problems in the 20th century, Wayang Jawa which takes the story of Prince Diponegoro. Wayang Kancil which takes the story of a deer that likes to steal food, Wayang Wahyu takes the story of Jesus Christ [3] and Pancasila. This puppet play was created by Harsana Hadisusena in 1946. The content of the story about the events of August 17, 1945. This play serves to educate about the philosophy of Pancasila and the 1945 Constitution [4].

As explained above, the various forms of wayang appearances and various sources of stories show that wayang appearances are very dynamic. This dynamism makes wayang thrive in the archipelago as cultural wealth. However, puppets that collaborate with calligraphy and story sources from Islamic books are embodied in a new puppet, namely Wayang Kekayon Khalifah. This puppet became unique when the calligraphy of the names of the figures and places are brought to life with a new source of the story, namely from the book Siroh Nabawiyyah. Especially during the performance is delivered with two sessions, namely seminar and performance. Performing technique with geguritan performance technique. The forms of collaboration that exist and stories built to shape the character of the nation and character will be discussed in the following writings with descriptive analysis. 


\section{METHODS}

The research method used is a descriptive analysis study. This is done to provide a description or descriptive of the data. This research describes Wayang Kekayon Khalifah Yogyakarta as a spectacle but also as a guide or education on Islamic teachings. It aims to help readers understand the Wayang Kekayon Khalifah Yogyakarta.

\section{RESULTS AND DISCUSSION}

Performing arts have the potential to be a means of communication and information transformation to society. This can be an effective means of da'wah in the time of wali sanga and Islamic preachers today. Performing arts can be used to disseminate various values, understandings concepts, ideas, views derived from Islam.

The form of visualization and story became the main concern in the development of da'wah. The use of puppetry in da'wah can be seen in the decision of the first Sultan of Demak with Wali Sanga in which they developed the forms of puppet images along with the equipment of the show and tried to compose the story that is not contrary to Tawhid [5]

Similarly with Wayang Kekayon Khalifah in the 21st century. The term Wayang Kekayon Khalifah comes from the word wayang which literary means shadow, kekayon means mountain. While the Khalifah means the leader of the Muslims that continue the teaching of Islam after the Prophet had passed away (or at the beginning of the Islamic leadership that is Khulafaurasyidin). So that Wayang Kekayon Khalifah is puppetry in the form of a tree or a mountain with the names of the companions of the Prophet, especially Khulafaurasyidin and other companions of the Prophet. In addition, some figures that played a role in spreading Islam in the archipelago are made by using sculpting techniques. Wayang Kekayon Khalifah is performed in a way of seminar and performent. The seminar was about the Wayang Kekayon Khalifah and the play performed is based on the event during that time. Performing is done with a narrated read (reading text) such as poetry with a mastermind tone which is accompanied with keprakan and dhodhogan.

Visualization as the difference between each figure is done through the calligraphy writing and the symbols that accompany it. Visualization of Wayang Kekayon Khalifah is, among others, Abu Bakr, Umar bin Khaththab, Uthman bin Affan and Ali Bin Abi Talib. In addition, there are also figures of the Prophet's companions, namely Thalhah bin Ubaidillah, Zubair bin Awwam, Abdurrahman bin Auf, Abu Ubaidah Bin Jarrah, and so on. Other figures are archipelago figures, namely Sunan Kalijaga, Kyai Pandanarang, and so on. This puppet in the form of a mountain contains nostrils ornaments as a symbol of plants or trees as a characteristic of the mountain. In addition, this puppet also has various specific symbols related to the depiction of each character. The source of the story of Wayang Kekayon Khalifah comes from Sirah Nabawiyah and Babad. The audience or congregation performance technique is in front of the color so that the audience can see the side or display of the play from the front.

Wayang Kekayon Khalifah was first made in midNovember 2013 at Ndalem Caritagama, Jetis Rt. 03 Tamantirto Kasihan Bantul Yogyakarta Indonesia. Here is the place in which the concept of Wayang Kekayon Khalifah appeared. The purpose of this puppet is intended as an education of the order of life that is based on Islam, expressing Islam, and learning Islam through Javanese culture. Apart from that, there is also love for Rasulullah. The unique thing about the appearance of this puppet is to convey Islam in different ways. This puppet is also considered to be a new color in the world of puppetry that already exists and can enrich the puppet culture.

The process of making Wayang Kekayon Khalifah is almost the same as making Wayang Kulit in general. Making Wayang Kekayon Khalifah takes about two weeks to a month depending on the craftsman. Wayang Kekayon Khalifah is done at one of the Tatah Sungging Leather Handicraft Centers located at Kasongan Street, RT 05 Gendeng Bangunjiwo Kasihan Bantul Yogyakarta Indonesia [6].

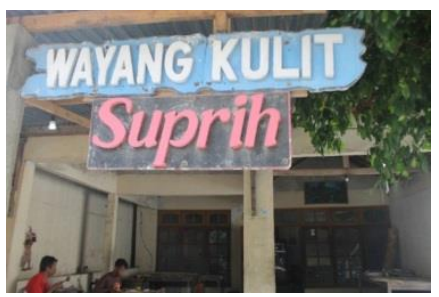

Fig. 1. Wayang Kulit Gendeng Kasihan Bantul Craft Center. Collaborating Calligraphy with Puppetry

The form of Wayang Kekayon Khalifah figures with their respective characteristics is as follows.

The figure of the Companions of the Prophet who became the Khalifah

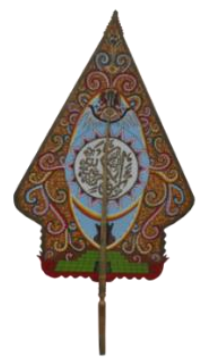

Fig. 2. Abu Bakar As-Shidiq

In simple terms, the depiction of one of these Khulafaurasyidin is to radiate the leadership of Abu Bakr which is almost the same as the Prophet. Because he was the successor of Rasulullah in terms of Muslim leadership, not in matters of prophethood. There is a crown symbol as a symbol of the leader/sultan. The white color in the middle represents purity and honesty, Abu Bakar As-Shidiq was the first person who believed in the events of Isra' Mi'raj when not a single person in Mecca did so. 


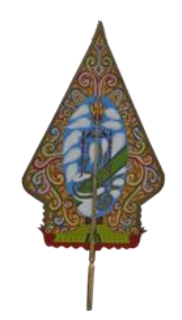

Fig. 3. Umar bin Khaththab

Umar bin Khaththab is seen as the spirit of Islam and the firm voice of Islam. The spirit of Umar bin Khaththab is pictured as a blazing fire, while for his firmness is a sword symbol. There is a Surah in the Qur'an, namely Thaha that opened his heart and made him converted to Islam.

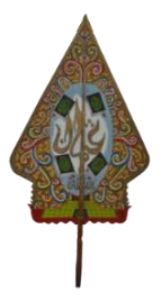

Fig. 4. Utsman bin Affan

Utsman bin Affan, one of the characters in Wayang Kekayon Khalifah. The presence of the Al-Quran symbol depicts the figure of Uthman Bin Affan as the Khalifah who played a major role in the bookkeeping of the Al-Quran.

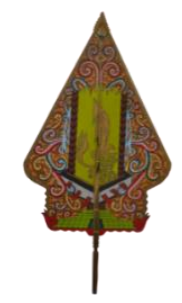

Fig. 5. Ali bin Abu Thalib

The presence of book symbols depicts the figure of Ali Bin Abi Talib as an intelligent Khalifah who was given The Key of Science as his title. In addition, there is a double-edged sword symbol (Zulfikar sword) a symbol of perseverance in war. The sword and the tongue of Ali bin Abu Talib are both "sharp".

The figure of the companions of the Prophet who did not become the Khalifah, but had a big role in Islamic preaching
The existence of the flames depicts the figure of Abdurrahman bin Auf who was persistent in being a Muslim. The presence of sea waves illustrates the relentless generosity. The sea has abundant wealth, extraordinary generosity is reflected in its relentless waves crashing/giving to the land. Giving here at its highest peak is to Allah and His Messenger. He was one of the people appointed to be the Khalifah but refused. However, every time there was a change of Khalifah he could not sleep and was restless for three days.

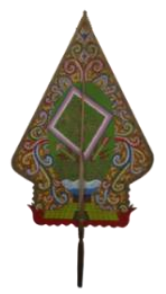

Fig. 7. Tholhah bin Ubaidillah

The existence of the arrows depicting figures Tholhah that fought to the death in the battle of Uhud. Until getting the title of Uhud war hero. Thalhah has an "ocean" heart, although he has no property to be endowed but still has a soul that can be "endowed" for Islam in the battle of Uhud. The companions said that the Uhud war belonged to Tholhah, it is recorded in history that this figure protected the Prophet until his body was tatu arang kranjang (his body was full of wounds).

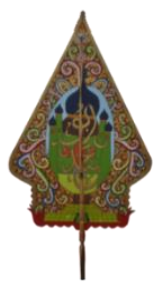

Fig. 8. Abu 'Ubaidah bin Jarrah

The depiction of the figure of Abu 'Ubaidah bin Jarrah with the mosque shows that this figure is very strong like a mosque. In addition to his physical strength, his heart is also related to the mosque. His title is "trustworthy strong man". With this title, Umar bin Khaththab once extended his hand for the election of the first Khalifah (after the death of the Prophet). However, Abu 'Ubaidah bin Jarrah did not want to precede Abu Bakr Ash Shiddiq who was once told by the Prophet to lead prayers while he was alive. Apart from that, Abu Bakr Ash Shiddiq was the person who invited Abu 'Ubaidah bin Jarrah to convert to Islam.

Description of the place that is the phase of da'wah of the Prophet SAW, namely

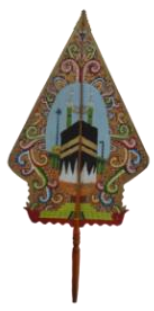

Fig. 9. Mecca 
Makkah al Mukaramah, one of the setting of place and time in the performance of Wayang Kekayon Khalifah. The presence of the Mecca symbol describes the phase of the prophet's da'wah in Mecca.

\section{Nusantara Figures}

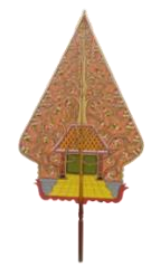

Fig. 10. Sunan Kalijaga

Sunan Kalijaga, the teacher of Sunan Pandanarang, is recognized by the Javanese people as a "holy teacher in the land of Java". Sunan Kalijaga has the ability to convey da'wah in a way that is full of wisdom, namely preaching with three principles momong, momor and momot. Momong means the will to nurture, guide, and direct. Because like children that can not take care of themselves, the caregiver must serve the needs of the child until the child can take care of himself. Momor means the will to be friends, socialize, be friends without having to consider the social status and position of each. Momot means the will to accommodate the aspirations of various walks of life. By means of the preaching of Sunan Kalijaga, Islam was successfully developed to the corners of Java [7].

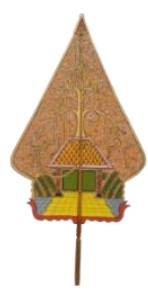

Fig. 11. Kyai Pandanarang

Kyai Pandanarang represents the people who are crazy about world affairs. All the pleasures of the world in the form of wealth, thrones, and women he pursued and obtained. After being confronted by Sunan Kalijaga, his life changed into the love of the hereafter. To achieve happiness in the hereafter, he must take a caring attitude. Purification of the soul is done with obedience to Allah and doing good deeds as well as by studying Islam. The last step is to do as his teacher did, which is to preach Islam.

As a student of Sunan Kalijaga, Kyai Pandanarang did $d a^{\prime} w a h$ as his teacher did. In carrying out Islamic da'wah, Sunan Kalijaga is known to like to disguise and act to show his weaknesses to hide the advantages he has [8].

\section{Current Forms}

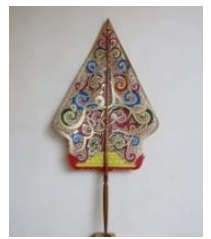

Fig. 12. Ki Lutfi Caritogomo
Ki Lutfi Caritogomo, one of the characters in Wayang Kekayon Khalifah. Ki Lutfi Caritogomo means Lutfi who tells about Islam, this puppet figure will narrate the story of Wayang Kekayon Khalifah.

\section{Dialogue of Islam with Javanese Culture}

Islamic Dialogue in Wayang as the Javanese culture was once performed by the Wali Songo in the period around the reign of Demak Kingdom. As a result, da'wah like this was accepted by the community, it was proven that many people embrace Islam. According to Zarkasi [9], puppet plays or performances are related to the elements of performance, namely, acting, chess, sabet, and karawitan. The following discussion is focused on the play or the story. A puppet plays is essentially a play that includes themes, messages, characters, and plot.

The play in the story of Wayang Kekayon Khalifah is based on the book Sirah Nabawiyah. The available plays are as follows: Mulabukaning Dakwah Rasul, Ja'far bin Abi Talib Duta, Wewarah Sejati Ngadhepi Wulan Suci, Jumenenging Kanjeng Nabi ing Madinah, Brubuhan Badar Kubra and Pandanarang Malik Grembyang.

\section{National Character Education and Character}

The performance art of Wayang Kekayon Khalifah contains the educational values of character in each of its plays. Some characters and character education are described as follows.

\section{a. Lakon Mulabukaning Dakwah Rasul}

The play Mulabukaning Dakwah Rasul tells about the early period of da'wah Rasulullah in which he silently preached. Khatijah, the wife of the prophet, was the first person that converted to Islam and was followed by the companions of the Prophet SAW. Then, in a wave, followed by the Arabian both men and women, from the rich and the poor. Islam is the subject of discussion. Until Allah SWT ordered Rasulullah to openly preach. Rasulullah SAW tirelessly came one by one to the houses of the people to invite the people of Mecca to convert to Islam. In addition, the prophet also forms a da'wah group to teach Islam to the community.

However, the Quraysh disbelievers do not like it so they insulted, criticized, fought the Prophet and other Muslims. Even so, Rasulullah still invited people with wisdom, but the infidels considered him guilty so that those who converted to Islam were partially arrested and persecuted. As for Rasulullah SAW, he was protected by Allah through his uncle, Abu Talib.

The story in the play Mulabukaning Dakwah Rasul or the beginning of dakwah, Rasulullah can be taken as an example of the perseverance of Rasulullah and his companions who hold fast to Islam. Conveying Islam or preaching and holding fast to Islam and inviting people to Islam is not an easy thing. However, Rasulullah remained steadfast in carrying the prophetic message.

\section{b. Lakon Ja'far Abi Thalib Duta}

This play depicts the Islamic ambassador in Wayang Kekayon Khalifah. It tells on the figure of Ja'far Abi Talib when he became the ambassador of the Muslims in Abyssinia 
during the period in which Muslims seek for shelter by migrating to the country of Abyssinia. This was done because in Makkah they were tortured by the infidels of Quraysh.

The story continues, knowing that the Muslims were accepted in the Abyssinia led by King Najasy, the infidels of Quraysh felt disliked and sent an ambassador to ask King Najasy to return the Muslims to Mecca. Although the infidels brought gifts for King Najasy, his diplomacy failed. Ja'far bin Abi Talib managed to give a good explanation by reciting the Quran Surah Maryam verse 29 to 33.

From the story of Ja'far bin Abi Talib a valuable lesson can be learned which is the image of an Islamic ambassador who dedicates himself to the welfare of Muslims and maintaining peace. What Ja'far bin Abi Talib did was simply because of the teachings of Islam.

Ja'far bin Abi Talib is one of the Islamic ambassadors who have a strong character, gentle, confident, his confident came from the truth he was telling. Although the risk to be arrested was huge, he voluntarily endowed himself with Islam. He dared to migrate to Abyssinia with his wife and other Muslims.

The role of Ja'far bin Abi Talib opens a wide range of insights and be a source of inspiration for Muslims today on how to become Islamic ambassadors to preach the teachings of Islam.

\section{c. Lakon Brubuhan Badar Kubra}

This play tells about the incredible victory in a war. The number of disproportionate forces between Muslims and infidels, Muslims number about 300 people and infidels number about 1000 people. There is a very strong and dramatic character-building story. The values of obedience, confidence, sacrifice, and love were instilled by Muhammad SAW.

The Muslims replied wholeheartedly by stating, "If you take us across this ocean, then you dive into it, we will surely dive with you". Muslims are patient in war, right in meetings. The play Brubuhan Badar Kubra contains character value that can be taken from Rasulullah's attitude as a Muslim leader. It is this spirit of leadership that can be used as a lesson for the younger generation. Apart from that, earnestness in worship will surely lead to help from Allah SWT.

\section{CONCLUSION}

Wayang Kekayon Khalifah warped with calligraphy and puppetry gives birth to a new area in the world of puppetry. Siroh Nabawiyah story and chronicle as the source of the story make Wayang Kekayon Khalifah able to accommodate the teachings of Islam in the Javanese culture. The values that Islamic teachings are contained in each play that is presented as a means of education and cultivation of education of the character of the nation and character.

The delivery of Islamic teachings full of blessings will be easily accepted by the community both among the grassroots and bureaucrats. A descriptive study of Wayang Kekayon Khalifah analysis gives an idea of the collaboration of Calligraphy art with Puppetry. In addition, it also gives an idea of the teachings of Islam can be connected with Javanese culture.

\section{REFERENCES}

[1] S. Sumarsam, Memaknai Wayang dan Gamelan: Temu Silang Jawa, Islam, dan Global. Yogyakarta: Gading, 2018.

[2] S. Sunarto, Gendeng Dusun Kerajinan Wayang Kulit Purwa Yogyakarta Kelangsungan dan Perubahannya. Yogyakarta. Penerbit Lembaga Penelitian ISI Yogyakarta, 2012.

[3] I. M. Bandem dan Murgianto, Teater daerah di Indonesia . Yogyakarta: Kanisius, 1999.

[4] Tim Senawangi, Ensiklopedi Wayang Indonesia. Jakarta. Penerbit Senawangi, 1999.

[5] A. Sunyoto, Atlas Wali Songo. Jakarta: Pustaka Ilman, 2016.

[6] M. Devi, Analisis Wayang Kekayon Khalifah Yogyakarta. Skripsi Program Studi Pendidikan Kriya Jurusan Pendidikan Seni Rupa Fakultas Bahasa dan Seni Universitas Negeri Yogyakarta, 2018.

[7] L. Lutfianto, Babad Demak Suntingan Teks, Terjemahan dan Analisis Struktur Naratif Episode Perjalanan Cerita Pandanarang dalam Memeluk Agama Islam Pupuh XXXVII-XXXIX. Thesis Interdiciplinary Islamic Studies Konsentrasi Islam Nusantara Pascasarjana UIN Sunan Kalijaga Yogyakarta, 2018.

[8] S. Saifullah, Sejarah dan Kebudayaan Islam di Asia Tenggara. Yogyakarta: Pustaka Pelajar, 2010

[9] E. Zarkasi, Unsur-Unsur Islam dalam Pewayangan; Telaah atas penghargaan Wali Sanga terhadap Wayang untuk media Da'wah Islam. Sala. Yayasan Mardikintoko, 1996. 